\title{
THE SEMITISMS OF THE FOURTH GOSPEL.
}

If one is to determine whether the author of the Fourth Gospel was a Jew from Palestine or, let us say, a hellenistic Christian native to Asia Minor, it is evidently of the utmost consequence to discover whether or no he was familiar with Hebrew and Aramaic. Yet amid the ever-increasing mass of Johannine studies in our language there is but little devoted to this aspect of the subject, and amid that little I do not know of any comprehensive survey of the evidence. It is partly; therefore, the practical needs of the lecture-room that have led me, with much diffidence, to attempt such a survey here; and I shall be well content if it be superseded by something better.

It appears necessary, as has been said, to take account both of Hebrew and Aramaic. For one whose native speech was Aramaic it would require very little effort to master Hebrew, and we can presuppose that none would know Hebrew who did not already speak Aramaic. Accordingly it is necessary, not merely to test the Old Testament quotations of the Gospel, to see whether knowledge of Hebrew must be assumed to explain them, but also to consider certain words and phrases which tend to shew familiarity with Aramaic. Although some individual items must carry much weight, still the argument is essentially a cumulative one, and even then one must remember that there is behind it a mass of internal evidence, detailed in many books, shewing the author's familiarity with people, places, customs, and the like. Taken in this concrete way, the evidence from language seems to me to'amount to solid proof; that is to say, it seems practically impossible to suppose that the author of this Gospel was anything but an Aramaic-speaking Jew.

The first consideration is that of style, and there is little need to confine it to Hebrew or Aramaic as such. Dr Drummond has admirably summed up what is to be said on the point in his Character and Authorship of the Fourth Gospel pp. 359-361, from which I may be allowed to cull a few sentences:

-We may compare the proem of John with the preface of Luke. The latter consists of a single sentence. In about the same space the former has no less than eleven sentences, either connected by кai or left without any connecting particle ... The purity of the Greek, combined with its general Hebraic structure, points to an author whose native tongue was 
Aramaic, and who learned Greek sufficiently well to speak and write it correctly, but too late in life to become imbued with the genius of the language'.

M. Loisy in his Quatrième Évangile (p. 146) has freely borne witness to the same phenomenon, although it was scarcely to the interest of his general thesis to do so: 'si les pensées se ressentent de l'influence hellénique, la phrase est tout hébraique'. It' is unnecessary to labour the point ; we pass to consider the Old Testament quotations.

Of these I propose to take first, three, which appear more certainly to indicate a knowledge of Hebrew, and afterwards four rather doubtful cases. (r) In John vi 45 we find a quotation from Isa. liv I 3 кai

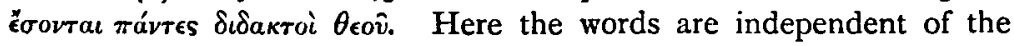
preceding verse, as in the Hebrew, whereas the Septuagint has kai

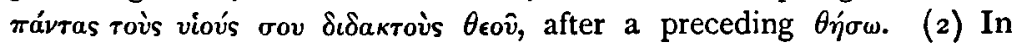

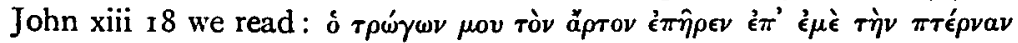
a $\pi \tau \epsilon \rho \nu$ $\sigma \mu{ }^{\prime} \nu$, which latter seems to. be correctly rendered in the current Latin psalter, magnificavit super'me supplantationem. Dr Drummond remarks, 'This correction cannot be accidental' (Character, \&oc. p. $3^{6} 3$ ).

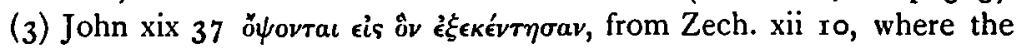

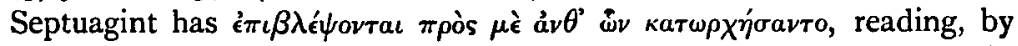
an interchange of letters, רקרו

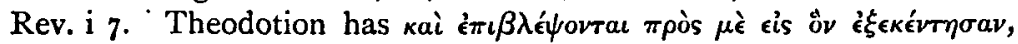

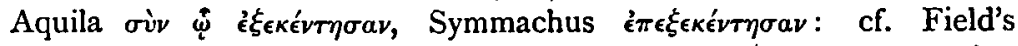
Origenis Hexapla, ad loc. This is the last of the three passages' in which Dr Westcott (St John's Gospel p. xiv) simply asserts that the Gospel agrees with the Hebrew against the LXX. Dr Drummond, besides this and the preceding Old Testament quotation, only speaks of John xii 40 ; on the present passage he remarks (p. 365) that 'the recourse to Theodotion is rather a makeshift, which is not supported by evidence, and, if it were, would not materially alter the argument'. Nevertheless he thinks that 'it is quite possible that, before any revision was actually undertaken, it may have become a matter of common knowledge, among those who cared for the Scriptures, that certain passages required emendation'. As against this it may be urged (I) that, on the face of it, the most likely hypothesis in any given case in which the Hebrew is followed against the LXX is knowledge of the Hebrew; (2) that the whole argument, as has been said, is of cumulative force.

To come now to the four cases that I have called rather doubtful, and first of all (I) to Dr Drummond's remaining passage, John xii 40

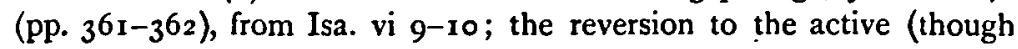
not to the imperative) of the Hebrew is rather striking, especially as the 
passive of the LXX is retained in Matt. xiii 15 . Next, working backwards, we have (2) the rather interesting case of John xii 15 from Zech! ix 9, where the Hebrew reads (R.V.), 'riding upon an ass, even upon a colt the foal of an ass', the waw being epexegetic. But the LXX has

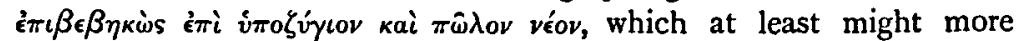
easily be understood of two animals; and that it is so understood in Matt. 'xxi 5 seems to be clear from the context (Matt. xxi 2-7). It is true that the colt alone is mentioned in Mark and Luke, but they do not quote the prophecy, and it may well be significant that St John, quoting the prophecy alone, should revert to the exact sense of the original. On the question of fact, it may be worth while to refer to a note in the Expository Times of May, 1917, where it is shewn how natural it would be for the mother-ass to keep the colt company. The third passage (3) is the word $\dot{\omega} \sigma \alpha v v a$ in John xii I 3 . It occurs twice in the same context in Mark, and thrice in Matthew, and therefore much stress cannot be laid upon it. Still, it represents a Hebrew cry (cf. Dalman, The Words of Jesus p. 222: Aramäische Grammatik, ed. 2, p. 249), and while it might be repeated from the primitive Aramaic story in the first two Gospels, the third shews us how a hellenistic writer might avoid it ; all the more so when, like St John, he was deliberately writing an entire gospel of his own, and not merely, so to speak, editing. common material. Perhaps we should note also in this connexion the cry $a \lambda \lambda \eta \lambda$ ovuá in Rev. xix I-6. Finally, (4) it seems not unlikely that, as I ventured to suggest in the Expositor for May, 1906 (p. 428), we may have in John ii 16 a reference preserved to the Hebrew of Zech. xiv 2I, always supposing. (with the Oxford Hebrew Dictionary) that 'should probably be translated 'trader' rather than Xavavaîos, as in the Septuagint.

The force of the argument from Old Testament quotations is heightened by the fact that, as Dr Westcott mentions (p. xiv), nowhere does the Gospel text agree with the.LXX against the Hebrew. In his 'additional note to John xviii $I$ ', where there might seem to be an exception, he shews from the LXX that the words $\tau \bar{\omega} \nu$. Ké $\delta \rho \omega \nu$. probably give the current Greek name, partly due no doubt to assonance with the Hebrew name 'Kidron', .

We pass 'on to consider a number of Aramaic words, generally explained by the author himself, which, taken cumulatively, point to his having at one time spoken the Palestine vernacular. The relation of English to Welsh in Wales, as the late Dr Moulton remarked in the; opening chapter of the Prolegomeria to his projected New Testament Grammar, is much like the relation of Greek to Aramaic in New Testament times; and we can easily imagine, a former native, after removal to England, recalling and explaining in his .memoirs Welsh terms that' 
would have no interest for an Englishman. In the study of the following words the writer is chiefly indebted to Dr Dalman's three works, the Words of Jesus and Aramäische Grammatik already referred to, and his Aramäisch-Neuhebräisches Wörterbuch. For the words discussed below the reader may be referred once for all to the indexes of the first two works.

First, then, we have (I) $\dot{\rho} \alpha \beta \beta \epsilon i$ (John eight times, Matt. four, Mark four, otherwise not in N.T.) which is translated the first time it is used (John i $3^{8}$ ), as is also the expanded form $\dot{\rho} \alpha \beta \beta$ ovve', the single time that it occurs (John xx 16 : otherwise only Mark x 51 ). Dr Dalman has much to say on this term (Words of Jesus pp. 324-340). The word (2) Mcroias is found in John i 42, iv 25, and not elsewhere in N. T., and is translated in both passages; the word appears to be based on

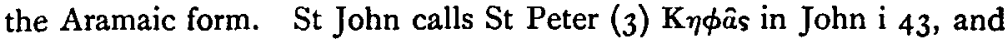
translates the term; it is used eight times by St Paul (I Cor. 4, Gal. 4), but otherwise not in N.T. St Paul was accustomed to call St Peter by

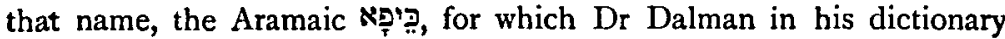
gives the first meaning as 'rock' ('Felsen'), citing Num. $x x 8$ in the Onkelos Targum. St Paul uses IÍ́tpos only in Gal. ii 7-8. It is a curious fact that the two New Testament writers often supposed to have been the most affected by hellenistic influences are also the most evidently at home in Aramaic. St John does not refer to the explanation of the name in Matt. xvi 18 , but gives the fulfilment of the promise there made (John xxi $16-17$ ), just as he gives the foreshadowing of the Holy Eucharist (John vi), but not the institution; such traits have their place amid the multitude of other indications that he was deliberately supplementing the Synoptics. He doubtless came to use İ́troos for $K_{\eta} \phi \hat{a} s$, but it is surely an authentic touch in his Gospel that he does not seem quite at home with the former, but

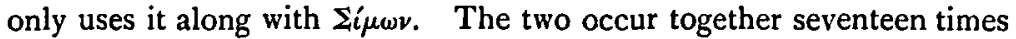
in the Gospel, and I'́t but always when the two names together have just preceded. The author seems never to have come to a familiar use of the new name; a friend does not easily change the name of his friend. Like the other evangelists, he represents Christ Himself as calling St Peter 'Simon': the only exception seems to be Luke xxii 34 : may not this latter passage contain a touch of irony? Such irony Christ could use, and St Paul too (e.g. Luke xi 48, 2 Cor. xi 19 ). In any case we may contrast all this with the simple 'Peter' of Acts, and we may compare the some-

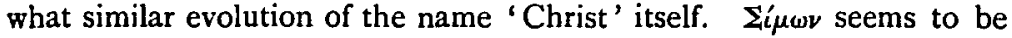
a Greek name, perhaps used by St Peter in Greek as the best equivalent of the Jewish name $\Sigma v \mu \epsilon \dot{\omega} v$, the form of his name found in Acts xv I4, 2 Peter i I, and not elsewhere. We may compare Saul taking the 
name of Paul, probably in part after Sergius Paulus; a fact which' appears to be hinted at in the Acts by the close proximity of the first mention of each (Acts xiii 7-9) : or Jesus, Onias's brother, taking the name of Jason (Josephus Antiq. xii 5. I). . Some other examples are given .in Prof. Deissmann's Bible Studies (ed. 2 p. 315), and we have already seen a curious parallel in the case of the torrent Kidron (p. 332).

Another interesting name is (4) $\mathrm{B} \eta \theta \zeta \alpha \theta \alpha^{\prime}$ in John $\mathrm{v} 2$, a reading adopted by Westcott and Hort, who thus forsake for once, and with some reluctance, the Codex Vaticanus. But in discussing the meaning of the name they fail to realize. that, as M. Lepin (L'Origine du Quatrième Evangile p. 400) points out, following upon H. Holtzmann and M. Loisy, it is probably translated by $\pi \rho \circ \beta a \tau i k \eta$ and therefore the 'Western' reading, with $\Pi_{\rho \circ \beta a \tau \iota \kappa} \dot{\eta}$ in the nominative instead of $\dot{\epsilon} \pi \dot{\imath} \tau \hat{\eta}$ $\pi \rho \circ \beta a \tau i \kappa \eta \hat{n}$, may be correct ; in which case it was the failure to grasp the real sense that led to the Sheep-gate being dragged in, presumably from Nehem. iii I, 32 ; xii 39 . The second part of $\mathrm{B} \eta \theta \zeta \alpha \theta a$ ' would presumably represent some such form as ${ }^{2}$ given by Levy in his Chaldäisches

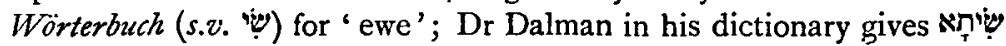
and also, like Levy, the variant to be passage of $\hat{e}$ into $a$ is not so very unusual; that of $\hat{\imath}$ is less frequent, yet by no means unknown. One may compare, for example, the Vatican. reading 'A $\sigma \sigma \alpha \rho \rho$ and its cognates in Josh. $\mathrm{xv}$ Io ; the last syllable of the word must represent שע. And in the case before us the extreme difficulty of pronouncing the two preceding consonants doubtless' contributed to the thinning of the following vowel.

Prof. Schmiedel remarks in the Encyclopaedia Biblica (art. John, vol. ii col. 2542) that the author of the Fourth Gospel (5) 'rightly

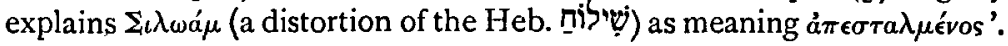
But Dr Souter appears to be following the more general opinion when he says in his Pocket Lexicon to the Greek N.T. that 'the name is Aramaic and really a substantive (= discharge or gushing forth of water)'. Hence it may not have been without a certain symbolic purpose that the evangelist rendered the meaning by a personal participle. Dr Drum-. mond, however, thinks (Character, \&c. p. 373) that the interpretation, ' though probably not the one from which the pool really received its name, is nevertheless grammatically admissible'. All the more, then, might it serve as a popular explanation. In any case there can be no doubt that the underlying root is $\Pi b \%$. The name (6) $\Theta \omega \mu \alpha \hat{s}$ occurs in four places in the Gospel (John xi 16 , xiv 5, xx 24-28, xxi 2), and only on the second occasion is it left untranslated; it therefore seems all the more natural to suppose that St Thomas really was a twin! In the case of the name (7) $\Gamma \alpha \beta \beta a \theta \hat{a}$ (John xix 13) the interest lies rather-in- 
the fàct that the evangelist does not translate it ; the piazza, if such we should call it, had different names in Greek and Aramaic, and he knew both. Such a case is not uncommon in Wales; Swansea is Abertawe and St Asaph is Llanelwy. Dr Dalman interprets Gabbatha as being 'the baldness of the forepart of the head' (Words of Jesus p. 7). He

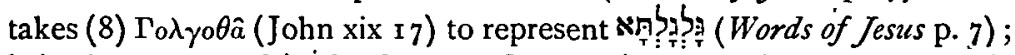
it is also translated in the first two Gospels (Matt. xxvii 33, Mark xv 22), but St Luke, whom we have already seen omitting $\dot{\omega} \sigma \alpha v a ́$ (p. 332), does not so much as name it.

I. now turn to the word (9) 'Irкaptwirns (John four times, Matt. twice, Mark once, Luke once ; note also 'I $\sigma \kappa a \rho \iota \omega \dot{\theta} \theta$, Mark twice, Luke once), but rather by way of answering a difficulty than of urging a further argument; for it might be said that the evangelist should have detected the Hebrew w that doubtless supplies the first syllable of the Greek word, and not have amalgamated it with the syllables representing the name of the place: Yet, in spite of the 'I $\sigma \kappa a \rho \iota \omega \dot{\theta}$, thrice found, it seems likely that

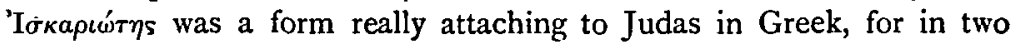
out of four cases St John is using it of Judas's father, Simon (John vi $7 \mathbf{x}$, xiii 26). Such curious anomalies do occur in the passing of words from language to language; we may compare the retention of the Arabic article in alcohol, alcove, algebra, almanac, \&c.

Closely akin to that from Aramaic words will be the argument, if such can be made, from words requiring the Aramaic to explain them. One such case there seems to me to be in the Fourth Gospel, and I have set it out in the Recherches de Science religieuse, published by the French Jesuit Fathers (vol iii p. 597, I91 2 : Le verbe í $\psi$ ov̀ dans saint Jean). To repeat only what is most essential, one has to explain bow the Jews understand the passive of í $\psi_{0} v$ in John xii 32,34 as necessarily implying death. There does not seem to be any sufficient warrant for this in Greek itself, but it can certainly be found in the verb פpl, which both in Hebrew and Aramaic means 'to raise up' (cf. Oxford Hebrew Dictionary), but in Ezra vi i i (cf. Bp Ryle ad loc., in Cambridge Bible for Schools and Colleges) implies impalement or crucifixion. Both in Aramaic and Syriac (cf. Levi, Buxtorf, and Payne

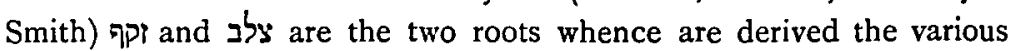
words concerned with crucifixion. ${ }^{1}$

Perhaps a word should also be added here on the words rí $\dot{\epsilon} \mu$ ì kai ooi, yuvau; (John ii 4), which I discussed at some length in three letters to the Tablet (February 17, March 3, April 7, 1917). ${ }^{2}$ The use of yoval seems to be absolutely Greek ; it is used, as Liddell and Scott put it,

1 [But see the following Note by Dr Burkitt ]

2 [See also Dr Burkitt's Note on the phrase in the Jourkal vol. xiii (1912) pp. $594 \mathrm{f}$.] 
'often as a term of respect and affection'. The main idiom, in its essential features, occurs eight times in the Old Testament and five times in the New; the Septuagint always reproduces the Hebrew idiom, so that no argument for the purpose of this article can be based upon it. It means laissez-moi tranquille, 'let me be', as the small French Crampon Bible puts it (in a note on John ii 4), but, en bonne ou mauvaise part, the tone may be friendly or unfriendly. More often it is unfriendly, but it is distinctly friendly in 2 Chron. xxxv $2 \mathrm{I}$, and the sequence sufficiently shews in what sense it was uttered here. The Hebrew idiom is concerned with persons; there are traces of a Greek idiom concerned with things. Demosthenes (contra Aphobum, ch. 12,

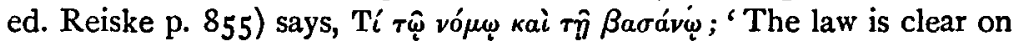
the point without any need to resort to torture'. Again, in Suetonius's Latin Lives of the Caesars, in a passage which I have not seen quoted

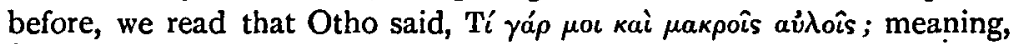
'Why did I not leave the long pipes (business) alone', and apparently referring to a bad omen when he was acting as augur (Suet. Otho, 7). We also have a similar expression used by Synesius, a Christian bishop

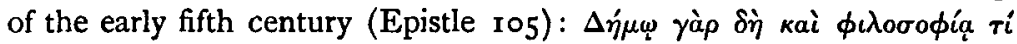
$\pi \rho o ̀ s ~ a ̈ \lambda \lambda \eta \lambda \alpha$; This is an excuse for his nolo episcopari, and is an important contribution to the explanation of the phrase.

Reference has been made once and again in the foregoing to the Apocalypse of John, but without serious attempt to build up a case from it. If once it were allowed to have the same author as the Fourth Gospel, the thesis set forth in this article could be greatly strengthened; but it seems unlikely that those who find a difficulty in the thesis would admit such a premise. Nor, truth to tell, does the thesis really need such support; taken, as was said at the outset, as one great cumulative argument, the evidence already adduced appears of itself to amount to solid proof.

Cuthbert Lattey.

\section{ON 'LIFTING UP' AND 'EXALTING'.}

Dr E. A. Abrott in his exegetical studies on the Gospels has a great deal to say about 'lifting up'. According to him, 'lifting up' in the Fourth Gospel always implies Christ's Passion and Ascension (Diatesserica vii, 2998 (xxiii) e). There can of course be no doubt that the Evangelist connects the 'exaltation' of the Serpent in the Wilderness with the Crucifixion (John iii I4, xii 32-34), and at the same time regards 